\title{
Cold Atmospheric Plasma Induces HMGB1 Expression in Cancer Cells
}

\author{
YONGDAE YOON ${ }^{1}$, BONGHYE KU $^{2}$, KEUNHO LEE $^{2}$, YONG JIN JUNG ${ }^{3}$ and SEUNG JOON BAEK ${ }^{1}$ \\ ${ }^{1}$ College of Veterinary Medicine and Research Institute for Veterinary Science, \\ Seoul National University, Seoul, Republic of Korea; \\ ${ }^{2}$ PSM Inc. 15F Mega Center, SKn Techno park, Seongnam, Republic of Korea; \\ ${ }^{3}$ Department of Internal Medicine, Seoul National University College of Medicine, \\ Seoul Metropolitan Government Boramae Medical Center, Seoul, Republic of Korea
}

\begin{abstract}
Background/Aim: Plasma medicine is a new field that provides great potential for the treatment of human diseases including cancer in addition to sterilizing the surface of skin and facilitating wound healing. Recently, nonthermal atmospheric plasma (or cold atmospheric plasma, CAP) was introduced, not only for denaturing cells and tissues, but also for operating under the threshold of thermal damage and for chemically inducing a specific response or modification. Materials and Methods: Microwave-mediated CAP was used in this study. Results: CAP increased highmobility group box 1 protein (HMGB1) expression, thereby increasing HMGB-1 secretion. In addition, we observed that the calreticulin (CRT) protein was concentrated at the cellular membrane when plasma was treated, representing immunogenic cell death. Conclusion: Overall, plasma treatment induces apoptosis via immunogenic cell death in cancer cells, implying a potential application to human cancer therapy and for the treatment of other human diseases.
\end{abstract}

Cancer is the second leading cause of death in the USA, and conventional therapeutic approaches including chemo/radio therapy could not face the current crisis. New technologies, concepts, or combination therapies are needed to improve the current situation. Plasma is an energy that consists of active

Correspondence to: Yong Jin Jung, Department of Internal medicine, Seoul National University College of Medicine, Seoul Metropolitan Government Boramae Medical Center, Seoul 07062, Republic of Korea. Tel: +82 1064211086, e-mail: jyj0601@snu.ac.kr; Seung Joon Baek, Laboratory of Signal Transduction College of Veterinary Medicine and Research Institute for Veterinary Science, Seoul National University, 1 Gwanak-ro, Gwanak-gu, Seoul 08826 , Republic of Korea. Tel: +82 1029690401, e-mail: baeksj@snu.ac.kr

Key Words: Cold atmospheric plasma, high-mobility group box 1 protein, apoptosis, colon cancer, thyroid cancer, calreticulin. electrons and ion radicals from gases. Plasma was originally proven to be an effective alternative to many existing sterilization methods, and it became commercially available for medical use in the 1990s. The temperature of non-thermal atmospheric plasma, so-called cold atmospheric plasma (CAP), is low at room temperature and does not require a vacuum system, making it possible to use in nanotechnology and biomedical applications (1). Subsequently, several devices have been developed using cold plasma ejectors (2). When a substrate is treated with CAP, chemical reactions are induced and active radicals are generated (3).

Exposure of mammalian cells and tissues to CAP can result in: mitochondrial membrane depolarization (4), changes in gene expression (5), cellular senescence (6), disruption of cell-=cycle progression $(3,7,8)$ and migration (9). Recent studies have shown that CAP induces tumor regression in vivo at high doses (8). Thus, plasma treatment offers the possibility of modifying tissues at the cellular level and removing diseased sections with minimal inflammation and damage, as well as suppressing infections (10). Interestingly plasma selectively triggers apoptosis of cancer cells without damaging the adjacent normal cells (11). Thus, it is clear that plasma with charged species could influence cell growth and cell homeostasis; however, the molecular mechanisms by which the active species of plasma (radicals and ions) interact with living cells and induce specific responses at the cellular level, remain to be determined. A recent review related to plasma applications in oncology medicine has reported that its clinical use strongly needs the development of standardized and reliable protocols, determination of the more efficient type of plasma for each type of cancer, and assessment of its efficacy in combination with conventional treatments (12).

Immunogenic cell death (ICD) is a type of tumor cell death which primes an anticancer immune response. In response to ICD, tumor cells expose calreticulin (CRT) on cell surface prior to death, and release damage-associated 
molecular pattern (DAMP) molecules, such as ATP during apoptosis or HMGB-1 upon secondary necrosis. These DAMPs stimulate the recruitment of dendritic cells into the tumor bed, the uptake and processing of tumor antigens, and the optimal antigen presentation to $\mathrm{T}$ cells. Therefore, the hallmarks of ICD include plasma-membrane translocation of CRT and extracellular HMGB-1 release. Furthermore, intercellular HMGB-1 has been linked to a novel tumor suppressor activity in prostate cancer (13).

In this study, CAP was found to increase apoptosis in colon and thyroid cancer cells by CRT translocation to the plasma membrane and HMGB-1 release to the extra cellular matrix. CAP induces, at least in part, immunogenic cell death and thus may be applied to cancer therapy. Overall, if plasma technology is combined with current cancer therapy including general surgery, it would greatly enhance prognosis of cancer patients.

\section{Materials and Methods}

Cell culture and reagents. HCT-116 and BCPAP cells were cultured in McCoy's 5A and RPMI 1640, respectively, supplemented with $10 \%$ fetal bovine serum (Thermo Fisher Scientific, Waltham, MA USA) and $1 \%$ penicillin/streptomycin (Gibco life technologies, Carlsbad, CA, USA). All cells were cultured at $37^{\circ} \mathrm{C}$ in humid conditions with $5 \% \mathrm{CO}_{2}$. Ant-HMGB-1 (sc-56698), anti-CRT (sc373863 ), and anti- $\beta$-actin (sc-47778) antibodies were purchased from Santa Cruz Biotechnology (Santa Cruz, Dallas, TX, USA). Anti-HSP 90 (\#4877) was purchased from Cell Signaling Technology (Danver, MA USA). Anti-Lamin A/C (mab636) was purchased from Invitrogen (Carlsbad, CA, USA). Anti- $\alpha$-tubulin (PM054) was purchased from Medical \& Biological Laboratories (Nagoya, Japan).

Microwave plasma. Microwave plasma system provides a great deal of flexibility for research and small-scale processing applications. Microwave power is easily supplied through coaxial cables and connectors to plasma device. In this machine, microwave electric field inside the microwave devices collide with the argon gas molecules to make corona discharge in atmosphere pressure. The discharge is generated and argon gas is ionized and it becomes Plasma. The typical forwarded power to plasma device is about 100 Watt, whereas measured reflected power is 0 Watt.

Apoptosis assay. Apoptosis was measured by using the Annexin VFITC apoptosis kit (K101, BioVision, Milpitas, CA, USA). HCT116 and BCPAP cells were seeded in $60 \mathrm{~mm}$ plates, treated with plasma, and further incubated at $37^{\circ} \mathrm{C}$ for $24 \mathrm{~h}$. Cells were prepared according to the manufacturer's protocol and apoptotic cells were detected by Lab ${ }^{\mathrm{TM}}$ Quanta SC flow cytometer (Beckman Coulter, Brea, CA, USA). The apoptosis results were analyzed by Flowing Software 2.5.1 (Centre for Biotechnology, Turku, Finland). Annexin $\mathrm{V}$ positive cells were considered as apoptotic cells.

Semi-quantitative reverse transcription-polymerase chain reaction $(R T-P C R)$. HCT-116 cells were grown in $60 \mathrm{~mm}$ plates and treated with plasma. Following further incubation for $24 \mathrm{~h}$, total RNA was isolated from the cells using TRIzol ${ }^{\circledR} \mathrm{LS}$ reagent (Invitrogen).
Subsequently, cDNA was synthesized from total RNA by Verso cDNA synthesis kit (Thermo Fisher Scientific). PCR was conducted using GoTaq ${ }^{\circledR} \mathrm{G} 2$ Green Master mix (Promega, Fitchburg, WI, USA) with hHMGB-1 and hGAPDH primers (hHMGB-1 forward, 5'- TTTTGTGCAAACTTGTCGGGAGG-3'; hHMGB-1 reverse, 5'-GCGATACTCAGAGCAGAAGAGG3'; hGAPDH forward, 5'GACCACAGTCCATGCCATCA-3'; hGAPDH reverse, 5'-TCCA CCACCCTGCTGTA-3'). The amplicon was electrophoresed on a $1.5 \%$ agarose gel with NEOgreen (NeoScience, Seoul, Korea).

Western blot analysis. Cells were lysed using RIPA buffer (GenDEPOT, Barker, TX, USA) supplemented with $100 \mu \mathrm{M}$ of phenylmethylsulfonyl fluoride and sodium orthovanadate. Cytoplasmic and nuclear fractions were prepared using cyto/nucl

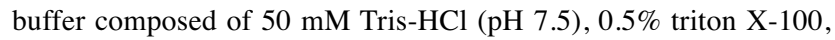
$137.5 \mathrm{mM}$ sodium chloride, $10 \%$ glycerol, $5 \mathrm{mM}$ EDTA, $1 \mathrm{mM}$ of phenylmethylsulfonyl fluoride and sodium orthovanadate. To prepare the cytoplasmic fraction cells were lysed in $1 \mathrm{ml}$ of cyto/nucl buffer, incubated on ice for $15 \mathrm{~min}$, and cell lysates were centrifuged at 13,000 rpm for $5 \mathrm{~min}$. The cytoplasmic fraction was the supernatant. The pellet was sonicated using Bandelin Sonopuls in $150 \mu \mathrm{l}$ of cyto/nucl buffer and centrifuged at $13,000 \mathrm{rpm}$ for 5 min, and the supernatant containing the nuclear fraction was aliquoted to a new tube. HMGB-1 secretion was measured after concentrating media using Amicon ${ }^{\circledR}$ ultra-15 (Merck Millipore, Burlington, MA, USA). The lysates were electrophoresed on a $10 \%$ SDS-PAGE gel and transferred onto nitrocellulose membrane. The membrane was then blocked with 5\% skim milk in Tris-buffered saline (TBS) with $0.5 \%$ Tween-20 (TBS-T). Primary antibodies $(1: 1,000)$ were diluted in $5 \%$ skim milk in TBS-T. The membrane was incubated overnight with the primary antibody at $4^{\circ} \mathrm{C}$ or at room temperature for $2 \mathrm{~h}$. After washing, the membrane was incubated for $1 \mathrm{~h}$ at room temperature with secondary antibody conjugated with HRP $(1: 10,000)$ diluted in $5 \%$ skim milk in TBST. Target protein was detected using PierceTM ECL blotting substrate (Pierce, Waltham, MA, USA). Proteins were visualized by Alliance Q9 mini system (UVITEC, Cambridge, UK).

Immunofluorescence. HCT-116 cells were seeded as $5 \times 10^{5}$ cells onto confocal dish (SPL Life Science, Pochen-si, Korea) and $12 \mathrm{~h}$ later were treated with plasma. Cells were washed with phosphatebuffered saline (PBS) and fixed by $4 \%$ paraformaldehyde for 10 min. After washing 2 times, the cells were blocked with $5 \%$ bovine serum albumin (BSA) in PBS for $1 \mathrm{~h}$. The cells were incubated with primary antibody (1:50) in 5\% BSA in PBS for $1 \mathrm{~h}$ and then incubated for $1 \mathrm{~h}$ with $4 \mu \mathrm{g} / \mathrm{ml}$ secondary antibody conjugated with Tetramethylrhodamine (TRITC) in 5\% BSA in PBS. After counterstaining with 4,6-diamidino-2-phenylindole, fluorescence was visualized using an LSM700 confocal microscopy (ZEISS, Oberkochen, Germany).

Statistical analysis. Statistical analysis was conducted with the student's unpaired $t$-test. The statistical significance of difference was marked as $* p<0.05, * * p<0.01$, and $* * * p<0.001$.

\section{Results}

Cold atmospheric plasma (CAP) induces apoptosis. Microwave plasma is a type of plasma, that has high frequency electro-magnetic radiation in the $\mathrm{GHz}$ range, 
A

\begin{tabular}{|l|c|c|}
\hline & $\begin{array}{c}\text { Middle frequency } \\
\text { plasma }\end{array}$ & $\begin{array}{c}\text { Microwave } \\
\text { plasma }\end{array}$ \\
\hline Frequency & $20 \sim 30 \mathrm{kHz}$ & $2.45 \mathrm{Ghz}$ \\
\hline $\begin{array}{l}\text { Temperature } \\
\text { Power } \\
\text { consumption }\end{array}$ & $>40 \sim 60^{\circ} \mathrm{C}$ & $<30^{\circ} \mathrm{C}$ \\
\hline $\begin{array}{l}\text { Industrial } \\
\text { Application }\end{array}$ & $\begin{array}{c}<200 \mathrm{~W} \\
\text { activation }\end{array}$ & $\begin{array}{c}\text { Medical } \\
\text { sterilization }\end{array}$ \\
\hline Plasma image & $\mathbf{I I I I}$ \\
\hline
\end{tabular}

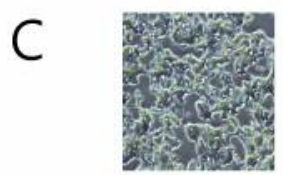

Control
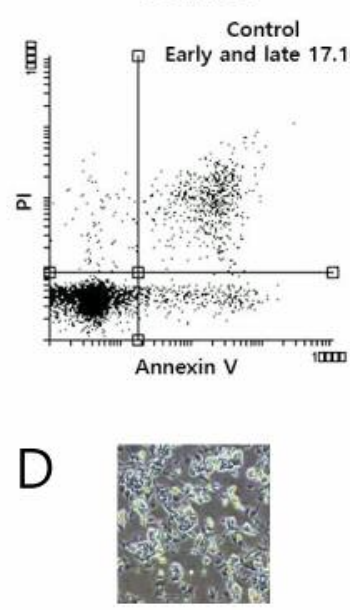

Control

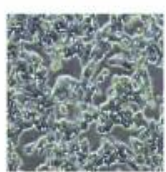

Gas only
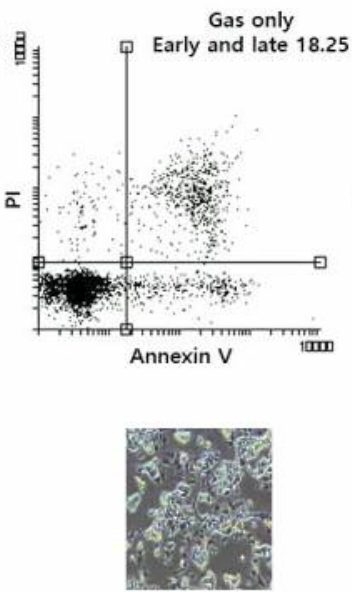

Gas only
B

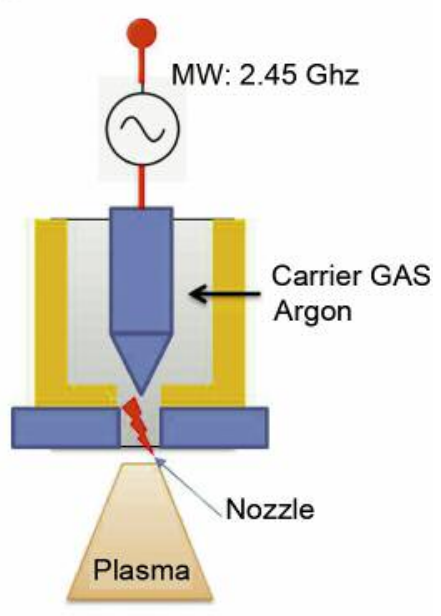

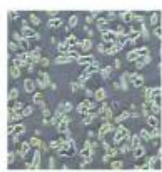

Plasma
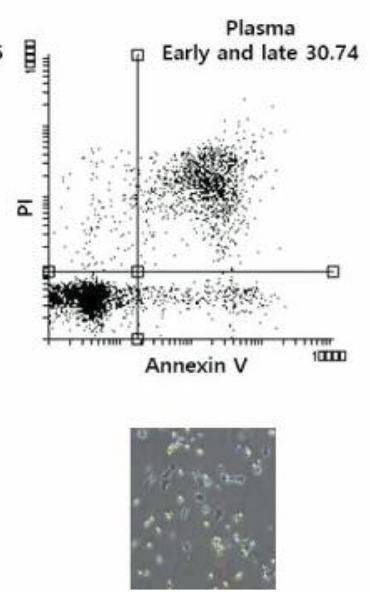

Plasma
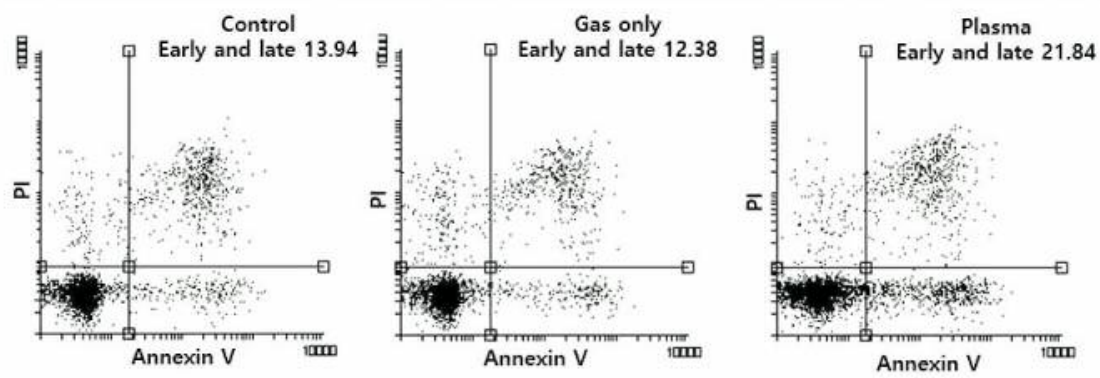

Figure 1. CAP induces apoptosis of cancer cells. (A) Physical comparison of middle frequency plasma and microwave plasma (Cold atmospheric Plasma). (B) Schematic diagram of the microwave CAP used in this study. (C) HCT-116 colorectal cancer cells and (D) BCPAP thyroid cancer cells were either treated with control (no treatment), gas only (30 sec), or plasma (30 sec, $100 \mathrm{Watt})$ and further incubated for $24 \mathrm{~h}$. The top panel, cells after 24 incubation and bottom panel, apoptosis analysis using the annexin V/PI kit. The percentages indicate the early and late apoptosis population. 
A

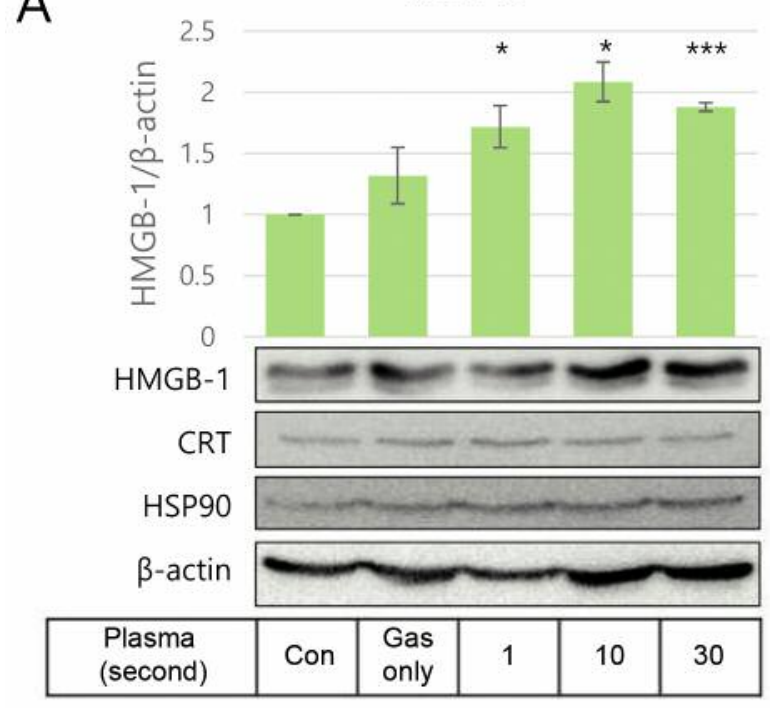

C

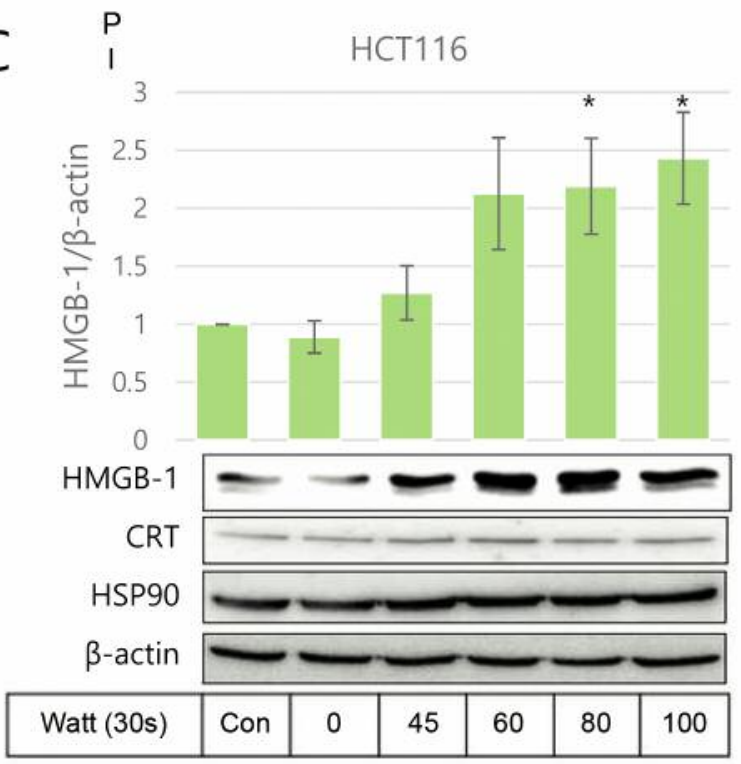

B

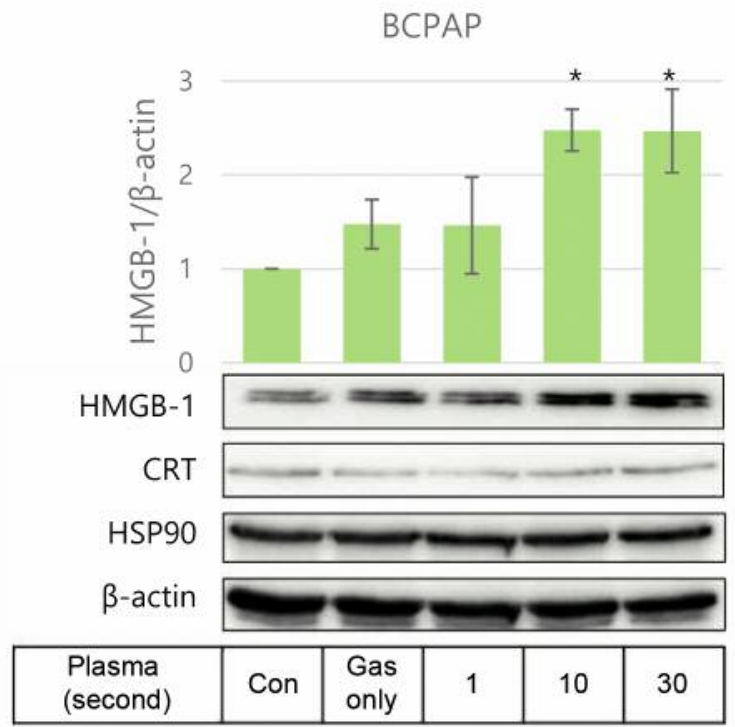

D

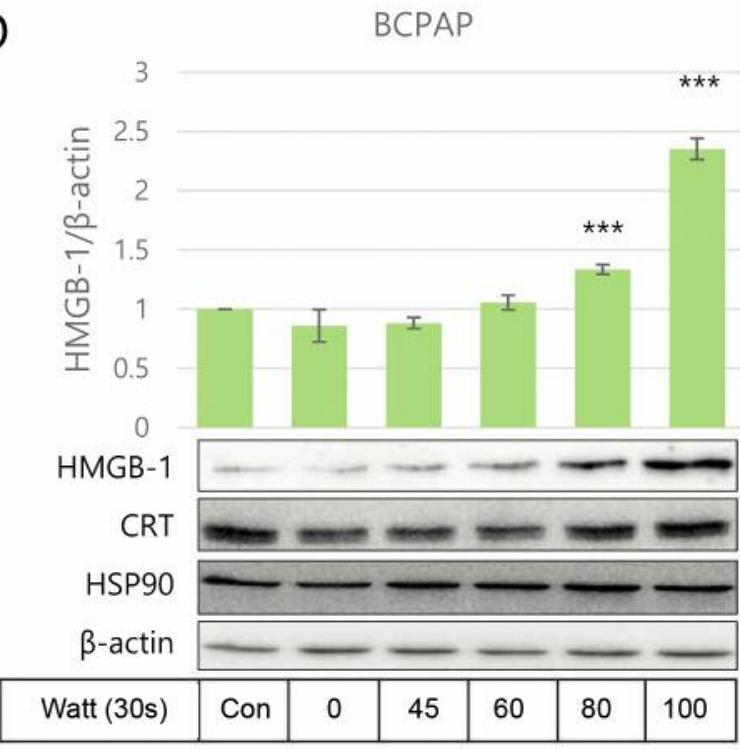

Figure 2. Expression of immunogenic cell death marker proteins upon CAP treatment. (A and B) HCT-116 and BCPAP cells were treated with 100Watt CAP for 1, 10, $30 \mathrm{sec}$ and further incubated for $24 \mathrm{~h}$. Cell lysates were subjected to western blot analysis using the indicated antibodies. Western blot results are representative of three independent experiments. (C and D) HCT-116 and BCPAP cells were treated with 0, 45, 60, 80, or 100-Watt CAP for $30 \mathrm{sec}$ and further incubated for $24 \mathrm{~h}$. Cell lysates were subjected to a Western blot analysis using the indicated antibodies. Values are expressed as mean $\pm S D$ of three replicates. ${ }^{*} p \leq 0.05$ and ${ }^{* * *} p \leq 0.001$ versus control cells.

which is capable of exciting electrodeless gas discharges. In this study, we used CAP induced by a microwave power, which provides a unique means of efficiently, transferring energy directly into the electron bonds in gas molecules. In this argon gas generated-plasma, ionization and chemical processes are directly determined by electron temperatures, and therefore is not as sensitive to thermal processes and the gas ion temperature compared to thermal plasma (14) (Figure
$1 \mathrm{~A}$ and $\mathrm{B})$. It has been reported that $\mathrm{CAP}$ induces apoptosis in several cancer cells mediated by immunogenic cell death (15-17). First, the effects of microwave CAP on the viability of colorectal and thyroid cancer cells, HCT-116 and BCPAP, respectively, were examined. The generation of plasma is controlled by Watt as described in Material section. After inducing CAP with 100 Watt for $30 \mathrm{sec}(3 \mathrm{~kJ})$, followed by incubation for $24 \mathrm{~h}$, cell morphology and apoptosis was 


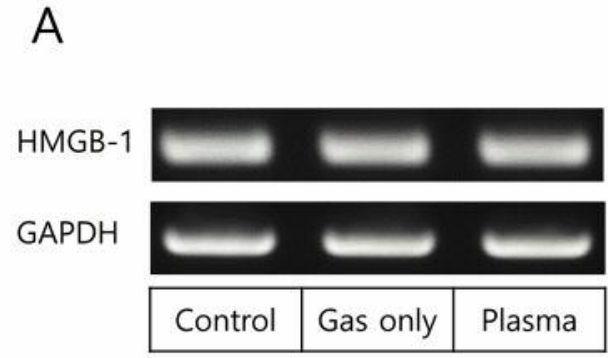

\section{B}

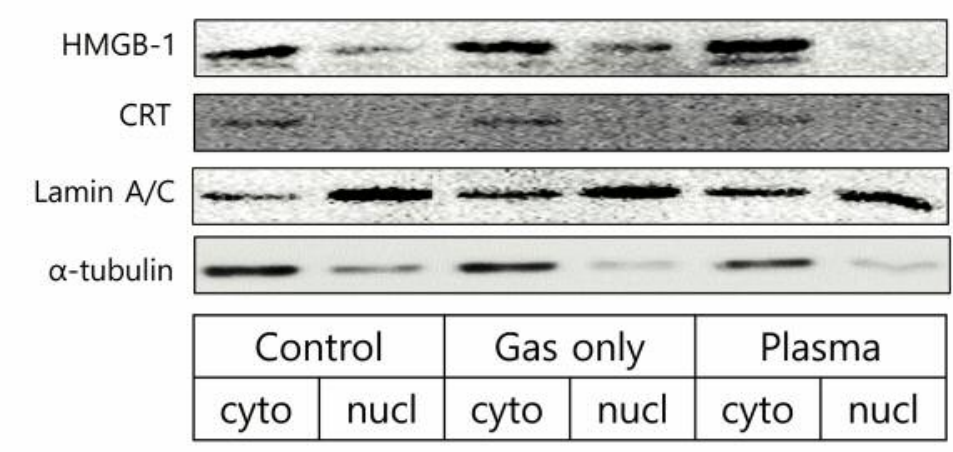

C

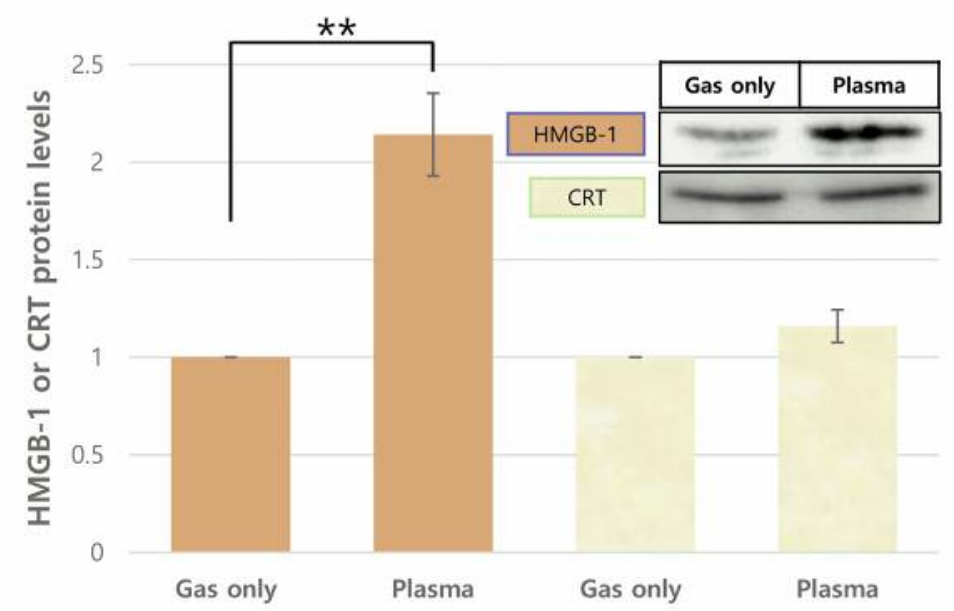

Figure 3. HMGB-1 expression and secretion are controlled by CAP. HCT-116 cells were treated with either control (no treatment), gas only $(30 \mathrm{sec})$, or plasma $(30 \mathrm{sec}, 100 \mathrm{Watt})$ and was further incubated for $24 \mathrm{~h}$. After total RNA isolation, cDNA was synthesized and RT-PCR was conducted using specific primers. The results are representative of two independent experiments. (B) HCT-116 cells were treated with CAP as described above, and cytoplasmic (cyto) and nuclear (nucl) fractions were isolated as described in the Materials and Methods" section. Lamin A/C or $\alpha$-tubulin was used as nuclear marker and cytoplasmic marker, respectively. (C) HCT-116 cells cultured in serum free media were treated with gas only $(30 \mathrm{sec})$ or plasma (30 sec, $100 \mathrm{Watt})$ and further incubated for $24 \mathrm{~h}$. The media was concentrated using Amicon® ultra-15 (Merck Millipore) and the concentrated proteins were subjected to Western blot analysis. Representative Western blot from three independent experiments is shown. ${ }^{*} p \leq 0.01$ versus gas only sample.

measured. As seen in Figure 1C and D, the viability of both HCT-116 and BCPAP cells was dramatically decreased. Measurement of apoptosis by the annexin V/propidium iodide kit, indicated that CAP induced early and late apoptosis. Treatment with gas only had no effect on apoptosis, indicating that apoptosis induction was mediated by plasma treatment.

CAP induces HMGB-1 expression, resulting in the immunogenic cell death in cancer cells. It has been reported that the CAP-induced apoptosis is related with immunogenic cell death (ICD) $(16,18)$. When immunogenic cell death is induced, several ICD marker proteins are secreted in the extracellular environment or presented on the cell membrane (19). Therefore, HMGB-1, CRT, and HSP90 expression was measured after treatment of HCT-116 and BCPAP cells with plasma. Following CAP treatment, HMGB-1 expression was increased in HCT-116 and BCPAP cells in a dose- and timedependent manner, whereas CRT and HSP90 expression was not altered. When cells were exposed to plasma at 100 Watt, HMGB-1 expression was increased in HCT-116 cells following treatment for 1,10 , or $30 \mathrm{sec}$ and in BCPAP cells following treatment for 10 or $30 \mathrm{sec}$; however, CRT and HSP90 expression was not affected following CAP treatment (Figure 2A and B). Significantly higher expression of HMGB-1 was observed following treatment with 80 and 

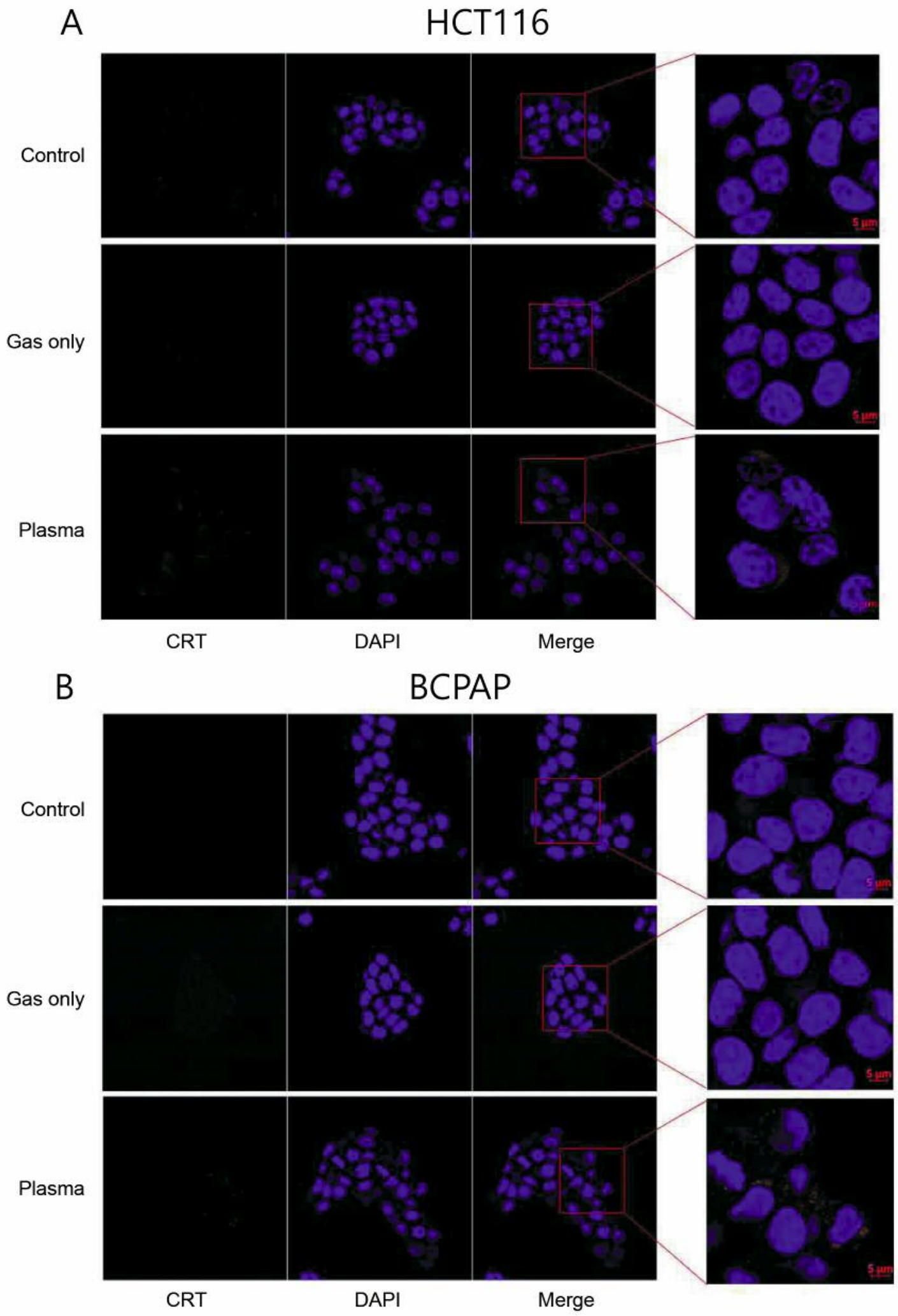

Figure 4. Effect of CAP on CRT localization. (A and B) HCT-116 and BCPAP cells were treated with control (no treatment), gas only (30 sec), or plasma (30 sec, $100 \mathrm{Watt})$ and further incubated for $24 \mathrm{~h}$. The cells were fixed with paraformaldehyde and stained by an anti-CRT antibody, followed by a secondary antibody conjugated with TRITC. Nuclei were stained with DAPI. 
100-Watt CAP for $30 \mathrm{sec}$ in both HCT-116 and BCPAP cells (Figure 2C and D). Similar results were obtained using Hur7 human liver cancer cells (data not shown).

CAP induces HMGB-1 protein levels. The increase in the levels of HMGB-1 protein by CAP was not at the result of activation of transcription (Figure $3 \mathrm{~A}$ ). It has been reported that HMGB-1 translocate to the cytoplasm in the process of immunogenic cell death (20) and that the release of HMGB1 is one of the key features immunogenic cell death capable of triggering a cognate immune response in vivo (19). Therefore, HMGB-1 expression in cytoplasmic and nuclear fractions was assayed. As seen in Figure 3B, CAP treatment resulted in decreased nuclear expression of HMGB-1 compared to control and gas-only treatment, whereas CRT expression was observed in the cytoplasmic fraction. Expression of HMGB-1 was also measured in the media. Plasma treatment resulted in increased secretion of HMGB$1 \mathrm{~d}$ (Figure 3C).

CAP treatment results in increased expression of CRT at the cell surface. CRT exposure at the cell surface is essential as an ER immunogenic signal for the induction of tumorassociated immune responses $(21,22)$, including dendritic cell maturation which activates secondary immune response (19). Since, no changes in the total levels of CRT were observed by western blot analysis any, subcellular localization of CRT in CAP-treated cells was assayed by immunohistochemistry. Without plasma treatment, CRT was barely detected in HCT116 and BCPAP cells; however, plasma treatment of HCT-116 and BCPAP cells resulted in detectable levels of CRT protein at the cell membrane (Figure 4A and B).

\section{Discussion}

Medical applications of plasma include hospital hygiene, antifungal treatment, dental care, skin diseases, chronic wounds, and cosmetics (23). Previous efforts have focused on detecting and identifying the basic processes of plasma production and delivery with the aim to design specific plasma machines for specific applications. It is time to move forward to elucidate the molecular mechanisms by which plasma affects biological systems in a specific manner. It has been shown that plasma induces apoptosis in cancer cells, whereas it leaves normal cells (endothelial cells) unaffected or even promotes their growth (24), indicating that plasma can be used in cancer treatment. Along these lines, in the current study, the optimum amount of plasma power and time of plasma exposure were determined in colorectal and thyroid cancer cells, HCT-116 and BCPAP, respectively, allowing us to use these cells in future experiments.

Considering the varying abundance and combinations of reactive oxygen species or reactive nitrogen species, the choice of gas is a crucial factor that may influence the efficacy of the treatment. In this system, argon gas and microwave-generated plasma was used to test the efficacy of the ablation of cancer cells upon plasma treatment. Since radicals induce cell death in cell culture systems (11), it is likely that these radicals contribute to plasma-induced apoptosis in cancer cells. Indeed, we have reported that using helium and oxygen gases results in the reduction of cell migration and invasion of human colorectal cancer cells (25). Oxygen addition to the helium plasma appears to improve the efficiency of the inhibition of migration and invasion of SW480 cells (3). In vitro results are consistent with the spectral data showing that increasing the input power and the addition of oxygen produces reactive oxygen radicals that affect cellular functions. In this study, the use of argon gas generated data similar to those of oxygen and helium gas. Argon gas was chosen to generate plasma because it is cheap and comparably easy to ionize; however, argon gasgenerated plasma with low energy may be used with a combination of other therapeutic strategies in superficial lesions (premalignant lesions, or early superficial cancer), hemostasis, disinfection and removal of microscopic residual cancer.

In addition to plasma energy, a plasma machine also produces UV and some ground-state molecules such as peroxides and ozone. Since these molecules and atoms play an important role in biology, the possibility that HMGB-1 induction is the result of their effects cannot be excluded. However, hydroxyl radicals radiate near a UV wavelength of 300-350 nm, while oxygen radicals can radiate visible light with a wavelength of $570-660 \mathrm{~nm}$. It is well known that UV with a range of $230-240 \mathrm{~nm}$ is the most effective for cell treatment and therefore, the UV magnitude may not have a significant consequence in our system. Instead, ozone may be considered a better component to treat cancer since it activates anti-oxidant enzymes. It has recently been reported that ozone may be a promising agent in anti-cancer therapy in head and neck squamous cell carcinomas (26). Since there is no report related to ozone and ICD, further analysis is needed to elucidate what molecules mediate the biological effects of plasma.

A limitation of plasm use is its tissue penetration. However, ROS generated by plasma may penetrate cells and affect cellular processes. ROS can induce DNA damage, which leads to the induction of apoptosis in cancer cells (27). Despite the limited data, there is every reason to assume that plasma is able to generate paracrine effects that propagate far into the cellular tissue. There may be unidentified side effects for long-term treatment with plasma; however, since the treatment will last at most $30 \mathrm{sec}$ and applied at low temperature, no significant side effects are expected.

Overall, plasma was found to increase total cellular levels HMGB-1 as well as its secretion to the extracellular matrix. 
This is interesting because HMGB-1 is key regulator of immunogenic cell death and an increase in HMGB-1 may enhance recruitment of immune cells near cancer cells.

\section{Conflicts of Interest}

The Authors declare that they have no competing financial, professional or personal interests that might have influenced the performance or presentation of the work described in this manuscript.

\section{Authors' Contributions}

Y.Y., B.K., Y.J.Y. and S.J.B. conceived the concept and designed the experiments. Y.Y. and B.K. performed the experiments and collected the results. K.L., Y.J.Y. and S.J.B. interpreted the results. The manuscript was principally written and revised by Y.Y and S.J.B. All the Authors critically reviewed the manuscript for important intellectual content and approved the final submitted manuscript.

\section{Acknowledgements}

This work was supported by the Research Institute for Veterinary Science, and BK21 PLUS Program for Creative Veterinary Science Research Center, Seoul National University, and by the National Research Foundation of Korea (NRF) Grant funded by the Korean government (2018R1A2B2002923) to SJB. This work was also supported by the clinical research Grant provided by the SMG-SNU Boramae Medical Center (02-2018-8) to JYJ and SJB.

\section{References}

1 Shashurin A, Keidar M, Bronnikov S, Jurjus RA and Stepp MA: Living tissue under treatment of cold plasma atmospheric jet. Appl Phys Lett 93(18): 2008. PMID: 29864663. DOI: 10.106/ j.scitotenv.2018.05.342

2 Laroussi M and Fridman A: Plasma medicine. Plasma Processes Polymers 5(6): 501-502, 2008. DOI: 10.1002/ppap.200800094

3 Kim CH, Kwon S, Bahn JH, Lee K, Jun SI, Rack PD and Baek SJ: Effects of atmospheric nonthermal plasma on invasion of colorectal cancer cells. Appl Phys Lett 96(24): 243701, 2010. PMID: 20628488. DOI: 10.1063/1.3449575

4 Ahn HJ, Kim KI, Hoan NN, Kim CH, Moon E, Choi KS, Yang SS and Lee JS: Targeting cancer cells with reactive oxygen and nitrogen species generated by atmospheric-pressure air plasma. PLoS One 9(1): e86173, 2014. PMID: 24465942. DOI: 10.1371/journal.pone .0086173

5 Andt S, Unger P, Wacker E, Shimizu T, Heinlin J, Li YF, Thomas HM, Morfill GE, Zimmermann JL, Bosserhoff AK and Karrer S: Cold atmospheric plasma (cap) changes gene expression of key molecules of the wound healing machinery and improves wound healing in vitro and in vivo. PLoS One 8(11): e79325, 2013. PMID: 24265766. DOI: 10.1371/ journal.pone.0079325

6 Arndt S, Wacker E, Li YF, Shimizu T, Thomas HM, Morfill GE, Karrer S, Zimmermann JL and Bosserhoff AK: Cold atmospheric plasma, a new strategy to induce senescence in melanoma cells. Exp Dermatol 22(4): 284-289, 2013. PMID: 23528215. DOI: $10-111 /$ exd.12127
7 Blackert S, Haertel B, Wende K, von Woedtke T and Lindequist $\mathrm{U}$ : Influence of non-thermal atmospheric pressure plasma on cellular structures and processes in human keratinocytes (hacat). J Dermatol Sci 70(3): 173-181, 2013. PMID: 23619096. DOI: 10.1016/j.jdermsci.2013.01.012

8 Kang SU, Cho JH, Chang JW, Shin YS, Kim KI, Park JK, Yang SS, Lee JS, Moon E, Lee K and Kim CH: Nonthermal plasma induces head and neck cancer cell death: The potential involvement of mitogen-activated protein kinase-dependent mitochondrial reactive oxygen species. Cell Death Dis 13(5): e1056, 2014. PMID: 24525732. DOI: 10.1038/cddis.2014.33

9 Brun P, Pathak S, Castagliuolo I, Palù G, Brun P, Zuin M, Cavazzana $R$ and Martines E: Helium generated cold plasma finely regulates activation of human fibroblast-like primary cells. PLoS ONE 9(8): e104397, 2014. PMID: 25127477. DOI: 10.1371/journal.pone. 0104397

10 Stoffels E: "Tissue processing" with atmospheric plasmas. Contributions to Plasma Physics 47(1-2): 40-48, 2007. DOI: 10.1002/ctpp.200710007

11 Zhang X, Li M, Zhou R, Feng K and Yang S: Ablation of liver cancer cells in vitro by a plasma needle. Appl Phys Lett 93: 021502, 2008. DOI: 10.1063/1.2959735

12 Dubuc A, Monsarrat P, Virard F, Merbahi N, Sarrette JP, Laurencin-Dalicieux S and Cousty S: Use of cold-atmospheric plasma in oncology: A concise systematic review. Ther Adv Med Oncol 10: 1758835918786475, 2018. PMID: 30046358. DOI: $10.1177 / 175885918786475$

13 Kang R, Xie Y, Zhang Q, Hou W, Jiang Q, Zhu S, Liu J, Zeng D, Wang H, Bartlett DL, Billiar TR, Zeh Iii HJ, Lotze MT and Tang D: Intracellular hmgb1 as a novel tumor suppressor of pancreatic cancer. Cell Res 27(7): 916-932, 2017. PMID: 28374746. DOI: $10.1038 / \mathrm{cr} .2017 .51$

14 Uhm HS, Hong YC and Shin DH: A microwave plasma torch and its applications. Plasma Sources Sci Technol 15(2): S26S34, 2006. DOI: 10.1088/096.-0252/15/2/S04

15 Hirst AM, Simms MS, Mann VM, Maitland NJ, O'Connell D and Frame FM: Low-temperature plasma treatment induces DNA damage leading to necrotic cell death in primary prostate epithelial cells. Br J Cancer 112(9): 1536-1545, 2015. PMID: 25839988. DOI: 10.1038/bjc.2015.113

16 Lin A, Truong B, Patel S, Kaushik N, Choi EH, Fridman G, Fridman A and Miller V: Nanosecond-pulsed dbd plasmagenerated reactive oxygen species trigger immunogenic cell death in a549 lung carcinoma cells through intracellular oxidative stress. Int J Mol Sci 18(5): e966 2017. PMID: 28467380. DOI: 10.3390/ijms 18050966

17 Song WC, Wang EJ, Gao Y, Wu QB, Rao SH, Wang HZ and Bao LZ: Low temperature plasma induced apoptosis in CNE-2Z cells through endoplasmic reticulum stress and mitochondrial dysfunction pathways. Plasma Processes Polymers 2018(15): e1600249, 2016. DOI: 10.1002/ppap.201600249

18 Lin AG, Xiang B, Merlino DJ, Baybutt TR, Sahu J, Fridman A, Snook AE and Miller V: Non-thermal plasma induces immunogenic cell death in vivo in murine ct26 colorectal tumors. Oncoimmunology 7(9): e1484978, 2018. PMID: 30228954 DOI: 10.1080/2162402X.2018.1484978

19 Galluzzi L, Buque A, Kepp O, Zitvogel L and Kroemer G: Immunogenic cell death in cancer and infectious disease. Nat Rev Immunol 17(2): 97-111, 2017. PMID: 27748397. DOI: 10.1038/nri.2016.107 
20 Kepp O, Senovilla L, Vitale I, Vacchelli E, Adjemian S, Agostinis P, Apetoh L, Aranda F, Barnaba V, Bloy N, Bracci L, Breckpot K, Brough D, Buqué A, Castro MG, Cirone M, Colombo MI, Cremer I, Demaria S, Dini L, Eliopoulos AG, Faggioni A, Formenti SC, Fučíková J, Gabriele L, Gaipl US, Galon J, Garg A, Ghiringhelli F, Giese NA, Guo ZS, Hemminki A, Herrmann M, Hodge JW, Holdenrieder S, Honeychurch J, Hu HM, Huang X, Illidge TM, Kono K, Korbelik M, Krysko DV, Loi S, Lowenstein PR, Lugli E, Ma Y, Madeo F, Manfredi AA, Martins I, Mavilio D, Menger L, Merendino N, Michaud M, Mignot G, Mossman KL, Multhoff G, Oehler R, Palombo F, Panaretakis T, Pol J, Proietti E, Ricci J-E, Riganti C, RovereQuerini P, Rubartelli A, Sistigu A, Smyth MJ, Sonnemann J, Spisek R, Stagg J, Sukkurwala AQ, Tartour E, Thorburn A, Thorne SH, Vandenabeele P, Velotti F, Workenhe ST, Yang H, Zong WX, Zitvogel L, Kroemer G and Galluzzi L: Consensus guidelines for the detection of immunogenic cell death. Oncoimmunology 3(9): e955691-e955691, 2014. PMID: 25941621. DOI: $10.4161 / 21624011.2014 .955691$

21 Colangelo T, Polcaro G, Ziccardi P, Muccillo L, Galgani M, Pucci B, Milone MR, Budillon A, Santopaolo M, Mazzoccoli G, Matarese G, Sabatino L and Colantuoni V: The mir-27acalreticulin axis affects drug-induced immunogenic cell death in human colorectal cancer cells. Cell Death Dis 25(7): e2108, 2016. PMID: 26913599. DOI: 10.1038/cddis.2016.29

22 Obeid M, Tesniere A, Ghiringhelli F, Fimia GM, Apetoh L, Perfettini JL, Castedo M, Mignot G, Panaretakis T, Casares N, Metivier D, Larochette N, van Endert P, Ciccosanti F, Piacentini M, Zitvogel L and Kroemer G: Calreticulin exposure dictates the immunogenicity of cancer cell death. Nat Med 13(1): 54-61, 2007. PMID: 17187072. DOI:10.1038/nm1523
23 Adachi T: Introduction to serial reviews: Biomedical application of non-thermal atmospheric pressure plasma and its usefulness. J Clin Biochem Nutr 60(1): 1-2, 2017. PMID: 28163375. DOI: 10.3164/jcbn.16-78

24 Kalghatgi S, Friedman G, Fridman A and Clyne A: Endothelial cell proliferation is enhanced by low dose non-thermal plasma through fibroblast growth factor-2 release. Ann Biomed Eng 38(3): 748-757, 2010. PMID: 20013154. DOI: 10.1007/s10439009-9868-x

25 Kim CH, Bahn JH, Lee SH, Kim GY, Jun SI, Lee K and Baek SJ: Induction of cell growth arrest by atmospheric non-thermal plasma in colorectal cancer cells. J Biotech 150(4): 530-538, 2010. PMID: 20959125. DOI: 10.1016/j.jbiotec.2010.10.003

26 Schulz S, Häussler U, Mandic R, Heverhagen JT, Neubauer A, Dünne AA, Werner JA, Weihe E and Bette M: Treatment with ozone/oxygen-pneumoperitoneum results in complete remission of rabbit squamous cell carcinomas. International J Cancer 122(10): 2360-2367, 2008. PMID: 18224691. DOI: 10.1002/ijc.23382

27 Srinivas US, Tan BWQ, Vellayappan BA and Jeyasekharan AD: Ros and the DNA damage response in cancer. Redox Biol:101084, 2018. PMID: 30612957. DOI: 10.1016/j.redox.2018.101084
Received March 15, 2019 Revised April 9, 2019 Accepted April 10, 2019 